\title{
Integrasi program SPARK dalam pendidikan jasmani terhadap peningkatan health-related fitness siswa
}

\author{
Heri Setiawan*, Nur Indri Rahayu \& Tite Juliantine \\ Universitas Pendidikan Indonesia \\ Jl. Dr. Setiabudhi No.229, Cidadap, Isola, Sukasari, Isola, Kec. Sukasari, Kota Bandung, Jawa Barat 40154 \\ *Corresponding Author. e-mail: heri.setiawann87@gmail.com
}

\begin{abstract}
Abstrak
Program SPARK sebagai salah satu program pelatihan substansial masih jarang diintegrasikan pada pembelajaran jasmani di sekolah. Tujuan penelitian ini adalah untuk menguji pengaruh integrasi program SPARK dalam pendidikan jasmani terhadap peningkatan health-related fitness serta menguji perbandingan antara pendidikan jasmani terintegrasi program SPARK dengan pendidikan jasmani tanpa program SPARK terhadap peningkatan health-related fitness siswa. Metode penelitian ini menggunakan matching onlypretest-postest control group design. Sampel penelitian ini adalah siswa kelas VII berjumlah 48 siswa. Pengambilan sampel dengan menggunakan teknik Intact Group. Instrumen yang digunakan dalam penelitian ini adalah FITNESSGRAM. Hasil penelitian menunjukan bahwa terdapat pengaruh program SPARK dalam pendidikan jasmani terhadap peningkatan health-related fitness siswa dan terdapat perbedaan yang signifikan antara siswa yang diberikan treatment program SPARK yang terintegrasi dalam pendidikan jamani dibandingkan siswa yang diberikan pendidikan jasmani tanpa program SPARK terhadap peningkatkan health-related fitness. Program SPARK dalam pendidikan jasmani merupakan wahana ideal untuk meningkatkan health-related fitness siswa yang dikemas secara sistematis dan terstruktur.
\end{abstract}

Kata Kunci: pendidikan jasmani, program SPARK, kebugaran terkait kesehatan

\section{Integration of the SPARK program in physical education towards the improvement of student health-related fitness}

\begin{abstract}
SPARK program as one of the substantial training programs is still rarely integrated into physical learning in schools. The purpose of this study was to examine the effect of the integration of the SPARK program in physical education on improving health-related fitness and to examine the comparison between the integrated physical education of the SPARK program and conventional physical education on improving student health related fitness. This research method uses Pretest-Posttest Control Group Design. The sample of this research was 48 students in grade VII, taking samples using the Intact Group technique. The instrument used in this study was Fitnessgram. The results showed that. There is an effect of the SPARK program in physical education on improving students' health-related fitness. There is a significant difference between students who are given SPARK treatment programs that are integrated in physical education compared to students who are given conventional physical education to improve health related fitness. SPARK program in physical education is an ideal method to improve the health-related fitness of students that is systematically prepared.
\end{abstract}

Keywords: physical education, SPARK program, health realated fitness

How to Cite: Setiawan, H., Rahayu, N. I., \& Juliantine, T. (2020). Integrasi program SPARK dalam pendidikan jasmani terhadap peningkatan health related fitness siswa. Jurnal Penelitian Ilmu Pendidikan, 13(2), 156-165. doi: https://doi.org/10.21831/jpipfip.v13i2.28979

Received 20-12-2019; Received in revised from 27-06-2020; Accepted 30-09-2020

This is an open-access article under the CC-BY-SA license. 
Jurnal Penelitian Ilmu Pendidikan, 13 (2), 2020 - 157

Setiawan, Rahayu \& Juliantine

\section{PENDAHULUAN}

SPARK (Sport, Play Activity, Recreation for Kids) dirancang untuk mengembangkan aktivitas fisik tingkat tinggi yang akan meningkatkan kebugaran terkait kesehatan, mengembangkan keterampilan gerakan yang menambah keberhasilan dan kegembiraan dalam aktivitas fisik, dan mendorong sosialisasi positif (Sallis et al., 1999; McKenzie, et al., 1997). SPARK memiliki dua bagian kegiatan yaitu kegiatan kebugaran berkaitan dengan kesehatan dan kegiatan kebugaran dengan keterampilan (Sallis et al., 1999). Kemajuan program ini karena adanya pengembangan dengan memodifikasi antara intensitas, durasi dan kompleksitas kegiatan. Meskipun fokus utama SPARK adalah pada pengembangan daya tahan kardiovaskuler, namun kegiatan ini juga mengembangkan kekuatan otot perut dan tubuh bagian atas (Herrick, et al., 2012; McKenzie, et al., 2016).

McKenzie et al. (1998) menyatakan guru pendidikan jasmani dapat merancang program pendidikan jasmani yang memuat pelatihan substansial untuk meningkatkan keterampilan manipulatif anak-anak. Tak jauh beda dengan pendapat McKenzie tersebut, Sallis et al., (1999), dalam penelitiannya menyimpulkan bahwa pelaksanaan program pendidikan jasmani di sekolah secara substansial tidak menimbulkan efek yang merugikan prestasi akademik siswa, bahkan dapat menimbulkan efek yang menguntungkan. Pernyataan McKenzie et a., dan hasil penelitian Sallis et al. tersebut semakin diperkuat dengan penelitian yang dilakukan oleh Cardon et al., (2009). Dalam hasil penelitiannya, Cardon et al., memperkuat temuan sebelumnya bahwa menghabiskan lebih banyak waktu untuk pendidikan jasmani tidak mengganggu kinerja akademik. Pejabat administrator sekolah didorong untuk dapat merancang program pendidikan jasmani di sekolah karena aktivitas fisik tersebut memberikan manfaat kesehatan fisik dan mental kepada para siswa. Selanjutnya menurut Fu et al., (2016), salah satu pelatihan subtansial yang dapat diprogramkan di sekolah adalah SPARK. Pelaksanaan program SPARK selama 9 minggu dapat meningkatkan MVPA (Moderate-to-Vigorous Physical Activity) di sekolah menengah secara signifikan melebihi rancangan pembelajaran program pendidikan jasmani pada umumnya. Penggunaan SPARK pada peserta didik menunjukkan peningkatan keterampilan manipulatif dan juga meningkatkan keterlibatan peserta didik dalam MVPA selama program pendidikan jasmani berlangsung (Belansky et al., 2016). Sedangkan penelitian yang dilakukan oleh Mostafavi et al., (2013) menunjukkan keberhasilan penggunaan SPARK pada pengembangan keterampilan motorik dasar anak-anak usia 4-6 tahun.

Kebugaran jasmani terkait kesehatan (health-related fitness) didefinisikan sebagai suatu kemampuan untuk melakukan aktivitas harian yang membutuhkan energi serta kualitas dan kapasitas yang diasosiasikan dengan rendahnya risiko munculnya penyakit hipokinetik (Hodges, et.al., 2015). Penyakit hipokinetik merupakan penyakit yang berhubungan dengan kurang gerak (inacitvity) atau gaya hidup sedenter (sedentary). Kehidupan sehari-hari yang kurang aktif bergerak atau berolahraga menjadi faktor risiko terjadinya penyakit hipokinetik (Rebanas, 2015). Karena itu, keadaan hipokinetik ini disebut juga penyakit perilaku (behavioral diseases). Selain itu, penyakit ini berlangsung secara menahun atau mempunyai "masa inkubasi" (masa laten) yang panjang, sehingga termasuk ke dalam penyakit kronik. Dari segi penyebab biologis/mikroorganisma, penyakit ini bukan disebabkan oleh kuman penyakit dan tidak menular sehingga disebut juga penyakit tidak menular (non-communicable disease). Adapun penyakit yang tergolong dalam penyakit hipokinetik adalah berbagai penyakit kronik yang berkaitan dengan pola hidup kurang aktif, yang di dalamnya termasuk kegemukan, diabetes mellitus, hipertensi, penyakit jantung, stroke, osteoporosis, osteoarthritis, dan kanker.

Kebugaran jasmani terkait kesehatan meliputi daya tahan jantung paru, daya tahan otot, kekuatan otot, kelentukan dan komposisi tubuh (Ortega, et al., 2008). Tingkat kebugaran jasmani terkait kesehatan sangat penting untuk siswa. Di mana siswa selalu dihadapkan dengan jadwal pelajaran dan kegiatan yang padat, terutama di sekolah-sekolah berasrama. Apabila kebugaran jasmani terkait kesehatan siswa meningkat maka dapat memberikan masukan yang penting terhadap peningkatan ketahanan jasmani siswa (Smith et al., 2014). Secara logika, apabila seorang siswa sakit akan berakibat pada hilangnya konsentrasi dalam belajar, sehingga ketika siswa memiliki kegiatan dengan intensitas cukup tinggi, siswa harus memiliki kebugaran terkait kesehatan yang baik. Dengan demikian tujuan dari setiap kegiatan yang dilakukannya dapat tercapai dengan hasil maksimal (Hastie et al., 2017). Kebugaran fisik terkait kesehatan juga merupakan indikator penting dari kesehatan yang baik, dan karenanya merupakan tujuan penting dari program pendidikan jasmani di sekolah (Ganley et al., 2011; Díez-Fernández et al., 2015). 
Salah satu dari tujuan pendidikan jasmani yaitu mengembangkan aspek kebugaran jasmani. Namun berdasarkan hasil survei yang dilakukan Mutohir, dkk. (2007) tentang tingkat kebugaran pelajar, memberikan hasil seperti berikut. Sebanyak $10,71 \%$ responden dari hasil survei masuk kategori kurang sekali, 45, 97\% masuk kategori kurang, 37,66\% masuk kategori sedang, dan sisanya $5,66 \%$ masuk kategori baik. Sementara itu, yang masuk kategori baik sekali sebanyak 0\%. Selanjutnya menurut temuan pada hasil penelitian Sulistiono (2014) tentang tingkat kebugaran jasmani siswa sekolah dasar dan menengah di Jawa Barat adalah sebagai berikut. Terdapat 42,27\% siswa sekolah dasar dengan tingkat kebugaran jasmani rendah, sedangkan pada siswa sekolah menengah pertama sebanyak $36,87 \%$, dan siswa sekolah menengah atas sebanyak $46,11 \%$. McKenzie, et.al (1991) dalam sebuah paparannya menyampaikan bahwa para guru pendidikan jasmani memberikan waktu hanya 3 menit untuk melaksanakan aktivitas fisik dari tingkat yang sedang hingga kuat yaitu kurang dari $10 \%$ dari waktu kelas. Hal ini jauh di bawah tujuan nasional bahwa anak-anak harus aktif setidaknya $50 \%$ dari waktu kelas pendidikan jasmani.

Kurikulum pendidikan jasmani sekolah menengah pertama mencantumkan pembelajaran kebugaran jasmani, yang di dalamnya mencakup pengertian tentang cara mendapatkan dan menjaga agar tubuh peserta didik tetap sehat dan bugar, sekaligus cara mengembangkan aspek kognitif, dan aspek afektif/sosial. Di mana seperti yang disampaikan Giriwijoyo (2017), bahwa Kurikulum PenjasOr lebih berorientasi kepada olahraga kecabangan, yang hal ini cenderung mengabaikan aspek kesehatan secara menyeluruh. Dengan demikian, pendidikan jasmani yang bermuara pada pencapaian kesehatan di antaranya kebugaran terkait kesehatan terlupakan. Sehingga guru pendidikan jasmani, harus memikirkan banyak aspek supaya siswa dapat bergerak aktif dan kebugaran jasmani mereka tetap terjaga.

Dalam proses pembelajaran, kurangnya pengalaman dan kreativitas guru pendidikan jasmani berpengaruh terhadap cara guru mengajar di lapangan. Cara guru pendidikan jasmani mengajar masih seperti pendidikan olahraga dengan menggunakan metode latihan dan komando serta minim pembaharuan di dalam pembelajaran (Hodges et al., 2017). Faktor lain yang juga menyebabkan rendahnya kebugaran, yaitu jumlah siswa yang banyak, sementara sarana dan prasarana terbatas sehingga partisipasi siswa menjadi tidak optimal. Di samping itu, proses pembelajaran kurang mempertimbangkan aspek karakteristik siswa secara keseluruhan seperti kurangnya pemanfaatan aspek bermain (Suherman, 2009).

Selain itu, hambatan yang dihadapi oleh para guru pendidikan jasmani dalam pelaksanaan pembelajaran kebugaran jasmani adalah jumlah jam pelajaran yang terbatas dalam pemberian materi pendidikan jasmani. Jumlah jam pelajaran dikatakan terbatas karena alokasi waktu pelajaran pendidikan jasmani di sekolah menengah hanya seminggu sekali (3 x 40 menit). Hal ini mengakibatkan kurangnya waktu/kesempatan peserta didik untuk melakukan suatu keterampilan gerak yang dipelajari. Sehingga penguasan keterampilan gerak peserta didik tidak maksimal, yang pada akhirnya membuat tujuan pembelajaran tidak tercapai. Lebih jauh dapat mengakibatkan hasil belajar siswa tidak mencapai standar minimum atau KKM. Hal ini dijelaskan oleh Giriwijoyo ( 2017:28):

“....terdapat batasan minimal tertentu untuk intensitas dan waktu pelaksanaan olahraga kesehatan agar dapat menghasilkan manfaat. Khususnya untuk dapat meningkatkan kemampuan fungsional perangkat pendukung gerak. Yakni diselenggarakan antara 3 sampai dengan $5 \mathrm{kali} /$ minggu (minimal 2x/minggu) dengan rentang intensitas antara $60-80 \%$ dari denyut nadi maksimal (DNM).”

Kesiapan siswa untuk melaksanakan proses pembelajaran jasmani tentunya dimulai dari memiliki diri yang sehat. Sehingga untuk memperoleh kesehatan, meningkatkan kebugaran fisik, dan memperoleh keterampilan motorik yang baik, siswa harus aktif secara fisik. Dengan keaktifannya dalam melaksanakan segala aktivitas, hal ini akan membentuk siswa dalam peningkatan kebugaran jasmani terkait kesehatan dan tentunya akan membuat siswa sehat secara jasmani. Kurangnya beraktivitas fisik atau aktivitas fisik tidak teratur telah diketahui berkaitan erat dengan timbulnya penyakit tidak menular dan penyakit degeneratif sebagai akibat proses penuaan, seperti penyakit kardiovaskuler, diabetes, kolesterol, obesitas dan juga osteoporosis (Warburton, et al., 2006; Candrawati, et.al.2016). Dengan demikian, penelitian ini bertujuan untuk mengetahui integrasi program SPARK dalam pendidikan jasmani terhadap peningkatan health-related fitness siswa. Juga untuk mengetahui perbedaan antara program SPARK dalam pendidikan jasmani dengan pendidikan jasmani tanpa program SPARK terhadap peningkatan health-related fitness siswa. 


\section{METODE PENELITIAN}

Penelitian ini dilaksanakan di SMP Islam Terpadu AL-Mukhtar. Sampel dalam penelitian adalah 48 siswa laki-laki dan perempuan kelas VII yang dibagi menjadi dua kelompok sampel yaitu sampel kelompok eksperimen dan kontrol. Berdasarkan desain penelitian yaitu matching only-pretestpostest control group design maka teknik pengambilan sampel menggunakan intact group. Deskripsi desain penelitian dapat dilihat pada tabel 1 .

Tabel 1. The Matching Only-Pretest-Posttest Control Group Design

\begin{tabular}{ccccc}
\hline Treatment Group & $\mathrm{M}$ & $\mathrm{O}_{1}$ & $\mathrm{X}$ & $\mathrm{O}_{2}$ \\
Control Group & $\mathrm{M}$ & $\mathrm{O}_{1}$ & $\mathrm{C}$ & $\mathrm{O}_{2}$ \\
\hline
\end{tabular}

(Fraenkel, 2011:257)

Dalam penelitian ini, kelompok eksperimen mendapat perlakuan kurikulum pendidikan jasmani terintegrasi dengan program SPARK. Sedangkan kelompok kontrol mendapat perlakuan kurikulum pendidikan jasmani tanpa integrasi program SPARK. Hal ini bertujuan untuk membandingkan hasil kelompok eksperimen dengan kelompok kontrol.

Perlakuan diberikan 2 kali seminggu dengan waktu 120 menit pada proses pembelajaran pendidikan jasmani dengan program SPARK. Sedangkan pendidikan jasmani tanpa program SPARK dilakukan selama 14 kali pertemuan. Ada penambahan 2 kali pertemuan untuk pelaksanaan pre-test dan post-test, dengan demikian total pertemuan yang dilaksanakan sebanyak 16 kali pertemuan.

Instrumen penelitian secara fungsional dibutuhkan untuk memperoleh data yang diperlukan untuk penelitian. Dalam penelitian ini, instrumen yang digunakan adalah The Fourth Generation Connecticut Physical Fitness Assessment yang diadaptasi sesuai kebutuhan dan kapasitas penelitian yang tentunya telah dimodifikasi sedemikian rupa sehingga tidak melenceng dari bentuk tes kebugaran jasmani itu sendiri (Plowman \& Mahar, 2013). Seperti tertera pada tabel 2.

Tabel 2. Fitnessgram/Activitygram Reference Guide $4^{\text {th }}$ Edition (Plowman \& Mahar, 2013)

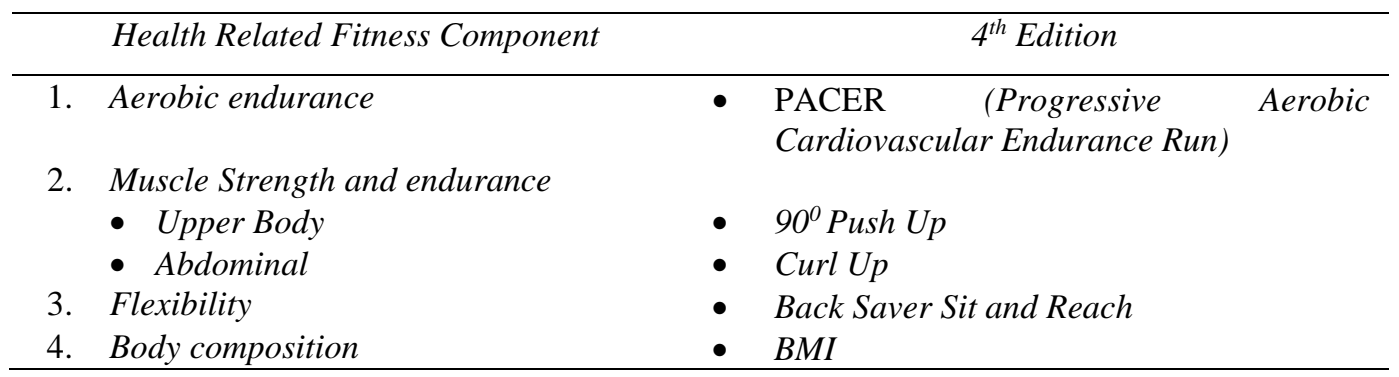

\section{HASIL DAN PEMBAHASAN}

\section{Hasil}

Perolehan skor SPARK pada saat pre-test dan post-test pada kelompok eksperimen dan kelompok kontrol diolah untuk mencari rata-rata (mean), simpangan baku (standard deviation) dan varians (variance). Berikut deskriptif data disajikan pada tabel 3.

Berdasarkan tabel 3 dapat disimpulkan bahwa nilai rata-rata health-related fitness pada kelompok eksperimen mengalami peningkatan yang signifikan dibandingkan dengan kelompok kontrol. Pada saat pre-test, kelompok eksperimen memperoleh nilai rata-rata $(\pi=135,8)$. Dan pada saat post-test memperoleh nilai rata-rata $(\pi=148,7)$. Sehingga terjadi peningkatan sebesar 12,9 pada kelompok eksperimen. Sedangkan pada kelompok kontrol, nilai rata-rata pada saat pre-test adalah $(\pi=$ $135,4)$ dan nilai rata-rata pada saat post-test adalah $(\pi=144,1)$. Hal ini berarti, nilai pada kelompok kontrol mengalami peningkatan sebesar 8,7. 
Jurnal Penelitian Ilmu Pendidikan, 13 (2), 2020 - 160

Setiawan, Rahayu \& Juliantine

Tabel 3. Perolehan Rata-rata Simpangan Baku dan Variance

\begin{tabular}{|c|c|c|c|}
\hline Variabel & Kelompok & \multicolumn{2}{|c|}{ Statistik } \\
\hline \multirow{6}{*}{ Pre-test } & \multirow{3}{*}{ Eksperimen } & Mean & 135,8039 \\
\hline & & Std. Deviation & 17,0263 \\
\hline & & Variance & 289,8938 \\
\hline & \multirow{3}{*}{ Kontrol } & Mean & 135,4561 \\
\hline & & Std. Deviation & 15,8924 \\
\hline & & Variance & 252,569 \\
\hline \multirow{6}{*}{ Post-test } & \multirow{3}{*}{ Eksperimen } & Mean & 148,7835 \\
\hline & & Std. Deviation & 17,7893 \\
\hline & & Variance & 317,5792 \\
\hline & \multirow{3}{*}{ Kontrol } & Mean & 144,14 \\
\hline & & Std. Deviation & 15,9872 \\
\hline & & Variance & 255,5907 \\
\hline
\end{tabular}

Jika digambarkan ke dalam diagram batang seperti gambar 1. Pada gambar 1, terlihat perbedaan peningkatan antara kelas eksperimen dan kelas kontrol, pada saat pre-test, maupun post-test.

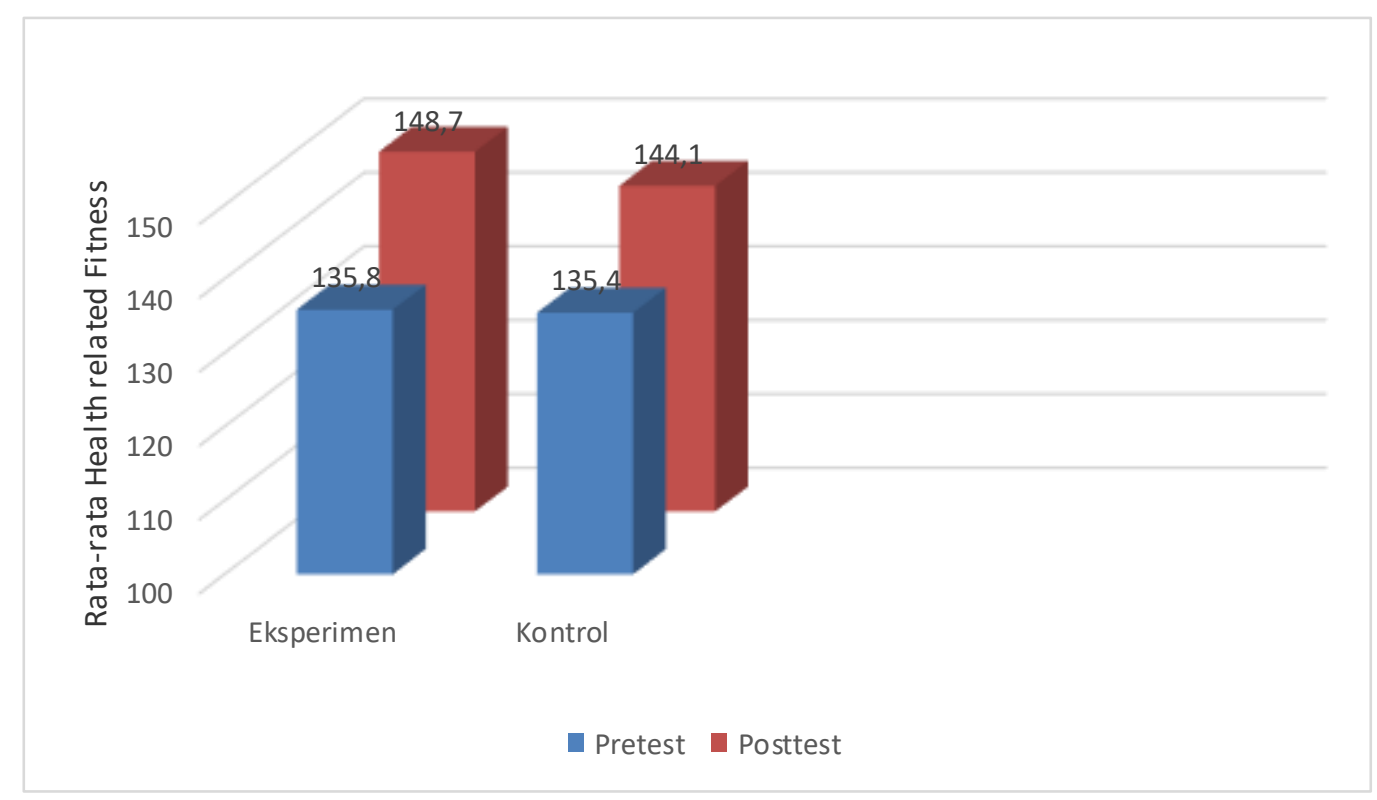

Gambar 1. Perbedaan rata-rata health-related fitness kelompok eksperimen dan kontrol

Uji prasyarat analisis dilakukan untuk menguji hipotesis dengan beberapa prosedur yakni uji normalitas dan uji homogenitas data. Uji normalitas dilakukan pada data pre-test dan post-test pada kelompok eksperimen dan kelompok kontrol. Pengujian normalitas (Test of normality) dilakukan dengan menggunakan uji shapiro-wilk pada taraf signifikansi $\alpha=0,05$. Sedangkan, uji homogenitas dilakukan terhadap data pre-test dan post-test pada kelompok eksperimen dan kelompok kontrol. Hal ini dilakukan untuk melihat apakah kelompok tersebut berasal dari variansi yang homogen sehingga kelompok tersebut bisa dibandingkan.

Tabel 4 menyajikan data uji normalitas dari data pre-test dan post-test pada kelompok eksperimen dan juga kelompok kontrol. Tabel 4 menyajikan data pembanding antara data pre-test dan post-test dan taraf nyata $(\alpha=0,05)$, dengan menggunakan uji shapiro-wilk. Hasil perbandingan menunjukan nilai signifikansi lebih besar dari $\alpha($ sig. $>0,05)$ pada kelompok eksperimen dan kelompok kontrol. Maka dapat disimpulkan bahwa data health-related fitness pada kedua kelompok berdistribusi 
Jurnal Penelitian Ilmu Pendidikan, 13 (2), 2020 - 161

Setiawan, Rahayu \& Juliantine

normal. Karena sesuai dengan kriteria pengambilan keputusan jika nilai sig. atau nilai probabilitas $\mathrm{P}>$ 0,05 (distribusi normal).

Tabel 4. Uji Normalitas Data Health Realted Fitness

\begin{tabular}{llcccc}
\hline \multirow{2}{*}{ Variabel } & \multirow{2}{*}{ Kelompok } & \multicolumn{3}{c}{ Shapiro-Wilk } & \multirow{2}{*}{ Keterangan } \\
\cline { 3 - 5 } & & Statistic & df & Sig. & \\
\hline \multirow{2}{*}{ Pre-Test } & Eksperimen & 975 & 23 & 809 & Normal \\
& Kontrol & 975 & 23 & 802 & Normal \\
\multirow{3}{*}{ Post-Test } & Eksperimen & 975 & 23 & 811 & Normal \\
& Kontrol & 969 & 23 & 673 & Normal \\
\hline
\end{tabular}

Langkah selanjutnya adalah menguji homogenitas. Uji homogenitas ini digunakan untuk mengetahui sampel penelitian tersebut berasal dari populasi yang homogen atau tidak. Pengujian kesamaan ragam (Homogenity of Variance) dengan menggunakan levene test. Dan hasilnya tertera pada tabel 5 .

Tabel 5. Uji Homogenitas Data Health Related Fitness

\begin{tabular}{rccccc}
\hline Variabel & Levene Statistic & df1 & df2 & Sig. & Keterangan \\
\hline Pre-Test & 159 & 1 & 44 & 692 & Homogen \\
Post-Test & 694 & 1 & 44 & 409 & Homogen \\
\hline
\end{tabular}

Berdasarkan hasil uji homogenitas pada tabel 5, dengan menggunakan uji levene test, diketahui bahwa data pre-test dan post-test dibandingkan pada taraf nyata $(\alpha=0,05)$ menunjukan nilai signifikansi lebih besar dari $\alpha$ (sig. $>0,05)$ pada kelompok eksperimen maupun kelompok kontrol. Dengan demikian dapat disimpulkan bahwa data variabel health-related fitness pada kedua kelompok variansi data adalah homogen. Karena sesuai dengan kriteria pengambilan keputusan jika nilai sig. atau nilai probabilitas $\mathrm{P}>0,05$, data berasal dari populasi memiliki varians sama (homogen).

Setelah data diasumsikan berdistribusi normal dan homogen langkah selanjutnya adalah pengujian hipotesis. Pengujian hipotesis menggunakan pendekatan uji t (paired sampel t test). Uji $\mathrm{t}$ dilakukan untuk mengetahui perbandingan selisih dua mean dari sampel yang berpasangan yaitu nilai health-realted fitness dari data pre-test dan post-test pada kelompok eksperimen yang telah diberikan program SPARK dalam pendidikan jasmani. Analisis data dilakukan dengan menggunakan statistik IBM SPSS satistics 23. Adapun hasil uji t untuk mengetahui perbandingan selisih dua mean (pre-test dan post-test) variabel health-realted fitness pada kelompok eksperimen, dapat dilihat pada tabel 6 .

Tabel 6. Uji t(Paired Sampel t test) Health Related Fitness

\begin{tabular}{lccc}
\hline Variable & $\mathrm{t}$ & $\mathrm{df}$ & Sig. (2-tailed) \\
\hline Kelompok Eksperimen & 17,567 & 22 & .000 \\
$\begin{array}{l}\text { Pre-test-Post-test } \\
\text { Kelompok Kontrol }\end{array}$ & & & \\
Pre-test-Post-test & 16.888 & 22 & .000 \\
\hline
\end{tabular}

Berdasarkan tabel 6, diperoleh nilai signifikansi (sig.) sebesar 0,000. Jika dibandingkan dengan taraf nyata $(\alpha=0,05)$, menunjukan nilai signifikansi pada kelompok eksperimen, lebih kecil dari $\alpha$ $(0,000<0,05)$. Dengan hasil tersebut, sesuai dengan kriteria pengambilan keputusan maka $H_{0}$ ditolak. Dengan demikian, data pada tabel 6 menunjukkan adanya peningkatan yang signifikan dari program SPARK dalam pendidikan jasmani dan kesehatan terhadap peningkatan health-related fitness siswa. Begitu juga pada kelompok kontrol, terdapat nilai signifikansi yang lebih kecil dari $\alpha(0,000<0,05)$, dengan demikian maka $H_{0}$ juga ditolak. $H_{0}$ ditolak artinya menunjukkan adanya peningkatan yang signifikan dari pendidikan jasmani terhadap peningkatan health-related fitness siswa. Sehingga, 
berdasarkan data pada tabel 6 dapat disimpulkan bahwa terdapat pengaruh yang siginifikan dari penerapan program SPARK dalam pembelajaran pendidikan jasmani dan kesehatan terhadap peningkatan health-related fitness siswa.

Setelah melakukan pengujian signifikasi pada kedua kelompok, tahapan selanjutnya adalah melihat signifikasi perbedaan dari peningkatan antara kelompok eksperimen dan kelompok kontrol. Di mana berdasarkan tabel 6 , kedua kelompok sama-sama mengalami peningkatan yang signifikan. Adapun hasil perhitungan dan uji signifikasi kedua kelompok dapat dilihat pada tabel 7. Tabel 7 menyajikan data untuk hasil perbedaan signifikansi kelompok eksperimen dan kelompok kontrol.

Tabel 7. Uji t (Independent Sampel t test) Health Related Fitness

\begin{tabular}{lllllll}
\hline \multirow{2}{*}{ No. } & Kelompok Sampel & $\overline{\boldsymbol{x}}$ & $\begin{array}{c}\text { Gain } \\
\sqrt{s^{2}}\end{array}$ & $\mathrm{t}_{\text {hitung }}$ & $\mathrm{t}_{\text {tabel }}$ & Keterangan \\
\hline 1 & Kelompok Eksperimen & 12,97 & 3,50 & & & \\
2 & Kelompok Kontrol & 8,68 & 2,40 & 4,84 & 2,01 & Signifikan \\
\hline
\end{tabular}

Secara sederhana prosedur analisis ini adalah membandingkan nilai rata-rata yang diperoleh dari program SPARK dalam pendidikan jasmani dengan pendidikan jasmani tanpa penerapan program SPARK. Selisih antara post-test dengan pre-test akan menunjukan kemajuan yang dialami siswa. Jika selisihnya berharga negatif, maka siswa tidak mengalami kemajuan bahkan mengalami kemunduran. Tetapi sebaliknya, jika selisihnya berharga positif maka dapat disimpulkan bahwa siswa telah mengalami kemajuan.

Jika memperhatikan tabel 7, diketahui selisih nilai dari program SPARK dalam pendidikan jasmani didapat rata-rata 12,97 dengan simpangan baku 3,50. Sedangkan nilai dari pendidikan jasmani didapat rata-rata 8,68 dengan simpangan baku 2,40. Setelah diolah dengan menggunakan uji t didapat $\mathrm{t}_{\text {hitung }} 4,84>\mathrm{t}_{\text {tabel }} 2,01$. Artinya terdapat perbedaan pengaruh yang signifikan antara program SPARK dalam pendidikan jasmani terhadap peningkatan health related fitness siswa daripada pembelajaran pendidikan jasmani tanpa penerapan program SPARK. Sehingga, berdasarkan data tersebut menunjukan bahwa program SPARK dalam pendidikan jasmani berpengaruh lebih baik terhadap peningkatan health-related fitness siswa.

\section{Pembahasan}

Program SPARK yang diterapkan dalam aktivitas pendidikan jasmani, merupakan salah satu program yang dapat membantu stakeholder dan para guru dalam mengoptimalkan peningkatan healthrelated fitness siswa. Program yang dirancang untuk mengembangkan aktivitas fisik tingkat tinggi yang akan meningkatkan kebugaran terkait kesehatan, mengembangkan keterampilan gerakan yang menambah keberhasilan dan kegembiraan dalam aktivitas fisik, dan mendorong sosialisasi positif. Hal ini terbukti dari hasil penelitian yang menunjukan bahwa pada kelompok eksperimen mengalami peningkatan yang signifikan terhadap health-related fitness siswa. Aktivitas pendidikan jasmani sebagai suatu keadaan yang terkendali dari kedua kelompok, menjadi tolak ukur peningkatan yang terjadi dari varibel health-related fitness. Berdasarkan hal itu terlihat dari hasil pengolahan data kelompok eksperimen (program SPARK dalam pendidikan jasmani) lebih tinggi peningkatannya dari pre-test ke post-test dibanding kelompok kontrol (pendidikan jasmani).

Hasil temuan data penelitian menunjukan bahwa kelompok eksperimen memberikan peningkatan yang lebih tinggi sebagaimana disajikan pada gambar 1 . Hal tersebut dibuktikan dengan perhitungan pada masing-masing kelompok, yaitu kelompok eksperimen (program SPARK dalam pendidikan jasmani) dan kelompok kontrol (pendidikan jasmani tanpa penerapan program SPARK).

Berdasarkan hasil penelitian yang sudah diuraikan sebelumnya dapat dinyatakan bahwa kelompok eksperimen yang diberikan program SPARK dapat meningkatkan kebugaran jasmani terkait kesehatan pada komponen Muscle Strength and Endurance (Upper Body and Abdominal), Flexibility, dan Aerobic Endurance. Hal ini dapat terlihat dari hasil pre-test dan post-test pada variabel Push Up 90', Curl Up, Back Saver Sit and Reach (R), Back Saver Sit and Reach (L) dan PACER. Namun pada komponen Body Compotion yaitu pada variabel Body Mass Index (BMI) tidak menunjukkan peningkatan yang signifikan. Selain itu pelaksanaan program SPARK menjadi lebih baik diterapkan 
pada pembelajaran pendidikan jasmani dibandingkan dengan pembelajaran pendidikan jasmani tanpa menggunakan implementasi program SPARK.

Penelitian ini memberikan pengetahuan tentang efektivitas program SPARK dalam pendidikan jasmani kepada kelompok anak-anak sekolah menengah pertama. Seperti banyak program aktivitas fisik berbasis sekolah lainnya, peningkatan aktivitas fisik pada anak dengan permainan yang bersifat rekreasi dilakukan dalam penelitian ini sekitar 120 menit tiap kali pertemuan selama tujuh minggu dengan program SPARK. Adanya peningkatan antara penerapan program SPARK dalam pendidikan jasmani dan pendidikan jasmani tanpa penerapan program SPARK. Hal tersebut berdasarkan hasil uji signifikan secara statistik menggunakan uji paired sampel t-test dengan nilai sig. $(000<0,05)$. SPARK dimulai sebagai program pendidikan jasmani sekolah dasar, dalam penelitian ini dilakukan terhadap sekolah menengah pertama. SPARK dikembangkan dari sudut pandang kesehatan masyarakat (Sallis et al.,1991). Program SPARK dirancang sebagai respons terhadap kebutuhan masyarakat untuk mengatasi kebugaran fisik yang rendah pada anak-anak (Sallis et al., 1997). Selain itu, kesenangan aktivitas fisik adalah konstruk motivasi yang penting dalam program SPARK, yakni aktivitas fisik berbasis sekolah (Burns, et al., 2017). Hal ini akan yang mempengaruhi anak untuk selalu bergerak aktif sehingga menunjang kesehatannya. SPARK telah terbukti meningkatkan MVPA (Moderate-toVigorous Physical Activity) untuk siswa selama hari sekolah selama 2 tahun (Sallis et al., 1997).

Pada uji hipotesis yang ketiga menunjukan bahwa terdapat perbedaan peningkatan antara kelompok eksperimen dan kelompok kontrol terhadap health-related fitness siswa, berdasarkan hasil uji signifikan secara statistik menggunakan uji independent sampel t-test dengan nilai sig. $(000<$ 0,05). Dari hasil perbandingan kedua kelompok tersebut pada kelompok eksperimen yang diberikan program SPARK terjadi peningkatan lebih baik dibandingkan kelompok kontrol tanpa program $S P A R K$. Hal ini terjadi karena dalam pendidikan jasmani dan kesehatan, siswa yang berada dalam kelompok eksperimen dituntut untuk berperan aktif dalam seluruh rangkaian kegiatan pembelajaran. Siswa yang tadinya kurang aktif dapat berperan aktif dan akhirnya dapat menunjang peningkatan health-related fitness (Fu, Gao, Hannon, Burns, \& Brusseau, 2016).

\section{KESIMPULAN}

Pendidikan jasmani dengan program SPARK dapat meningkatan health-related fitness siswa. Kedua pendidikan Jasmani dengan program SPARK lebih baik dibandingkan pendidikan jasmani tanpa program SPARK terhadap peningkatan Health Related Fitness Siswa. Program SPARK dalam pendidikan jasmani merupakan wahana ideal untuk meningkatkan health related fitness siswa yang di kemas secara sistematis dan terstruktur. Dalam situasi ini siswa tidak hanya mempelajari teknik dan taktik saja dalam pendidikan jasmani tetapi siswa dapat meningkatkan health related fitness setiap dalam proses pembelajaran, meskipun dalam pelaksanaannya siswa dituntut dalam aktivitas yang tinggi tetapi siswa dapat mengikuti semua aktivitas program yang diberikan dengan penuh rasa kegembiraan, kesenangan, semangat hal ini karena program SPARK dirancang dalam aktivitas dalam konsep latihan, olahraga, permainan, dan rekreasi.

\section{UCAPAN TERIMA KASIH}

Peneliti mengucapkan terima kasih kepada kepala sekolah, guru dan siswa SMP Islam Terpadu ALMukhtar.

\section{DAFTAR PUSTAKA}

Belansky, E. S., Cutforth, N., Kern, B., \& Scarbro, S. (2016). Disseminating evidence-based physical education practices in rural schools: The san luis valley physical education academy. Journal of Physical Activity and Health, 13(9), 1002-1009. https://doi.org/10.1123/jpah.2015-0467.

Burns, R. D., Fu, Y., \& Podlog, L. W. (2017). School-based physical activity interventions and physical activity enjoyment: A meta-analysis. Preventive Medicine, 103(May), 84-90. https://doi.org/10.1016/j.ypmed.2017.08.011.

Candrawati, S., Sulistyoningrum, E., Pranasari, N., Fisiologi, L., Kedokteran, F., Jenderal, U., ... Test, S. (2016). Senam aerobik meningkatkan daya tahan jantung paru dan fleksibilitas. Jurnal 
Kedokteran Brawijaya, 29(1), 69-73. https://doi.org/10.21776/ub.jkb.2016.029.01.14.

Cardon, G. M., Haerens, L. L., Verstraete, S., \& De Bourdeaudhuij, Ii. (2009). Perceptions of a school-based self-management program promoting an active lifestyle among elementary schoolchildren, teachers, and parents. Journal of Teaching in Physical Education, 28(2), 141154. https://doi.org/10.1123/jtpe.28.2.141.

Díez-Fernández, A., Sánchez-López, M., Gulías-González, R., Notario-Pacheco, B., García-Prieto, J. C., Arias-Palencia, N., \& Martínez-Vizcaíno, V. (2015). BMi as a mediator of the relationship between muscular fitness and cardiometabolic risk in children: A mediation analysis. PLOS ONE, 10(1), 1-15. https://doi.org/10.1371/journal.pone.0116506.

Fraenkel, J., Wallen, N., \& Hyun, H. (2011). How to design and evaluate research in education. New York: McGraw-Hill.

Fu, Y., Gao, Z., Hannon, J. C., Burns, R. D., \& Brusseau, T. A. (2016). Effect of the SPARK program on physical activity, cardiorespiratory endurance, and motivation in middle-school students. Journal of Physical Activity and Health, 13(5), 534-542. https://doi.org/10.1123/jpah.2015-0351.

Ganley, K. J., Paterno, M. V., Miles, C., Stout, J., Brawner, L., Girolami, G., \& Warren, M. (2011). Health-related fitness in children and adolescents. Pediatric Physical Therapy, 23(3), 208-220. https://doi.org/10.1097/PEP.0b013e318227b3fc.

Giriwijoyo, H.Y.S. Santosa (2017). Fisiologi kerja dan olahraga (fungsi tubuh manusia pada kerja dan olahraga. Jakarta: PT RajaGrafindo Persada.

Hastie, P. A., Chen, S., \& Guarino, A. J. (2017). Health-related fitness knowledge development through project-based learning. Journal of Teaching in Physical Education, 36(1), 119-125. https://doi.org/10.1123/jtpe.2016-0151.

Herrick, H., Thompson, H., Kinder, J. \& Madsen, K. A. (2012). Use of SPARK to promote afterschool physical activity. The Journal of School Health, 82(10), 457-462. https://doi.org/10.1111/j.1746-1561.2012.00722.x.

Hodges, M. G., Kulinna, P. H., van der Mars, H., \& Lee, C. (2015). Knowledge in action: Fitness lesson segments that teach health-related fitness in elementary physical education. Journal of Teaching in Physical Education, 35(1), 16-26. https://doi.org/10.1123/jtpe.2014-0102.

Hodges, M., Kulinna, P. H., Lee, C., \& Kwon, J. Y. (2017). Professional development and teacher perceptions of experiences teaching health-related fitness knowledge. Journal of Teaching in Physical Education, 36(1), 32-39. https://doi.org/10.1123/jtpe.2016-0107.

McKenzie, T. L. (1991). Physical education's role in public health. Research Quarterly for Exercise and Sport, 62(2), 124-137. https://doi.org/10.1080/02701367.1991.10608701.

McKenzie, Thomas L., Sallis, J. F., Kolody, B., \& Faucette, F. N. (1997). Long-term effects of a physical education curriculum and staff development program: SPARK. Research Quarterly for Exercise and Sport, 68(4), 280-291. https://doi.org/10.1080/02701367.1997.10608009.

McKenzie, T.L., Alcaraz, J. E., Sallis, J. F., \& Faucette, F. N. (1998). Effects of a physical education program on children's manipulative skills. Journal of Teaching in Physical Education, 17, 327341. https://doi.org/10.1123/jtpe.17.3.327.

McKenzie, T. L., Sallis, J. F., Rosengard, P., \& Ballard, K. (2016). The SPARK programs: A public health model of physical education research and dissemination. Journal of Teaching in Physical Education, 35(4), 381-389. https://doi.org/10.1123/jtpe.2016-0100.

Mostafavi, R., Ziaee, V., Akbari, H., \& Hosseini, S. H. (2013). The effects of SPARK physical education program on fundamental motor skills in 4-6 year-old children. Iranian Journal of Pediatrics, 23(2), 216-219.

Mutohir, T. C. \& Maksum, A. (2007). Sport development index (konsep, metodologi dan aplikasi). Jakarta: PT INDEKS.

Ortega, F. B., Ruiz, J. R., Castillo, M. J., \& Sjöström, M. (2008). Physical fitness in childhood and adolescence: A powerful marker of health. International Journal of Obesity, 32(1), 1-11. https://doi.org/10.1038/sj.ijo.0803774.

Plowman, S. A., \& Mahar, M. T. (2013). Fitnessgram/activitygram reference guide (4th Edition). Fitnessgram/activitygram reference guide (4th Edition), 1-202. https://doi.org/10.1055/s-00331334967.

Rebanas. (2015). Arti kata "hipokinetik." Retrieved from http://206.189.83.49/kamus/kesehatan/hipokinetik. 
Sallis, J. F., Lewis, M., McKenzie, (1991). Physical education's role in public health. Research Quarterly for Exercise and Sport, 62(2), 124-137. https://doi.org/10.1080/02701367.1991.10608701.

Sallis, J. F., Lewis, M., McKenzie, T. L., Kolody, B., Marshall, S., \& Rosengard, P. (1999). Effects of health-related physical education on academic achievement: Project spark. Research Quarterly for Exercise and Sport, 70(2), 127-134. https://doi.org/10.1080/02701367.1999.10608030.

Sallis, J. F., Lewis M., McKenzie, T. L., Alcaraz, J. E., Kolody, B., Hovell, M. F., \& Nader, P. R. (1997). Project SPARK. Annals of the New York Academy of Sciences, 699(1 Prevention an), 127-136. https://doi.org/10.1111/j.1749-6632.1993.tb18844.x.

Smith, J. J., Eather, N., Morgan, P. J., Plotnikoff, R. C., Faigenbaum, A. D., \& Lubans, D. R. (2014). The health benefits of muscular fitness for children and adolescents: A systematic review and meta-analysis. Sports Medicine, 44(9), 1209-1223. https://doi.org/10.1007/s40279-014-0196-4.

Suherman. (2009). Revitalisasi pengajaran dalam pendidikan jasmani. Bandung: Bintang WarliArtika.

Sulistiono, A. A. (2014). Kebugaran jasmani siswa pendidikan dasar dan menengah di Jawa Barat. Jurnal Pendidikan Dan Kebudayaan, 20(2), 223. https://doi.org/10.24832/jpnk.v20i2.140.

Warburton, D. E. R., Nicol, C. W., \& Bredin, S. S. D. (2006). Review health benefits of physical activity: the evidence. DOI: 10.1503/cmaj.051351. 